Dhaka Univ. J. Biol. Sci. 27(2): 163-173, 2018 (July)

\title{
ASSESSMENT OF HEAVY METALS AND THERMAL PROPERTIES OF SOIL-RICE-HUSK SYSTEM COLLECTED FROM THREE DISTRICTS OF BANGLADESH
}

\author{
Farzana Yasmin, Rajia Sultana and Md. Zakir Sultan* \\ Centre for Advanced Research in Sciences, University of Dhaka, \\ Dhaka-1000, Bangladesh
}

Key words: Heavy metals, Soil-rice-husk system, Industrial pollution

\begin{abstract}
This study was conducted to evaluate the contamination of heavy metals and their thermogravimetric properties in the soil-rice-husk system. Heavy metals concentration was determined by Atomic Absorption Spectroscopy (AAS) and thermal property was also analyzed by using Thermo Gravimetric Analyzer (TGA). Metals uptake in rice crop grown in soils of three different areas (Savar, Chapainawabganj and Gazipur) in Bangladesh was studied. Soil, rice husk and rice samples were analyzed after microwave acid digestion. Heavy metals concentration detected in rice samples decreases in the following order as $\mathrm{Fe}>\mathrm{Mn}>\mathrm{Zn}>\mathrm{Cu}>\mathrm{Ni}>\mathrm{Co}>\mathrm{Cd}>\mathrm{Pb}$. The metal content in husk was higher than in corresponding rice. Fe concentration was higher than other metals in soil, husk and grain samples. The concentrations of $\mathrm{Cd}$ and $\mathrm{Pb}$ in the soil were found to be below the detection limit and the order of the other heavy metals as $\mathrm{Fe}>\mathrm{Mn}>\mathrm{Zn}>\mathrm{Cu}>\mathrm{Ni}$. The thermal properties of the soil-ricehusk system did not show any significant visible variation during this experiment except for the soil of the Gazipur areas. The residual mass obtained from the TG thermogram helps to make a relation between the quality of soil and the rate of uptake of heavy metals by rice or its husk.
\end{abstract}

\section{Introduction}

Rice is one of the most important and widespread cereals in the world. It is the staff of life for 3 billion people, mainly in Asia( ${ }^{(1)}$, contributing over $70 \%$ of the energy and $50 \%$ of the protein provided by their daily food intake. Rice (Oryza sativa, Poaceae) provides the bulk of the human diet throughout Asia. In the last report of European Commission, India was presented as the first country for rice production with $19 \%$ of export. It is the staple food of Bangladesh, which has significant uses of human nutrition ${ }^{(2)}$. The economy of Bangladesh depends on the agriculture, mainly rice. As of 2016, it employs $47 \%$ of the total labor force and comprises $16 \%$ of the country's GDP. Bangladesh is the fourth largest rice producing country in the world(3). Different types of rice (Aush, Aman or Boro) are cultivated in Bangladesh throughout the year. Aman (broadcast and transplanted) is generally cultivated in December-January, Boro in March - May and Aus

*Author for correspondence: <zakir.sultan@du.ac.bd>. 
in July-August cropping seasons seasons. Among these cropping transplanted Aman is most important and occupied about $46 \%$ of the rice cultivated land in $2009-2010^{(4)}$.

Heavy metals may have a serious impact if they are released into the environment even in trace quantities(5). These can enter into the food chain from aquatic and agricultural ecosystems and threaten human health indirectly ${ }^{(6)}$. Whereas food crops may be exposed to heavy metal through contaminated soil or atmospheric dispersal of such metals from industrial areas, human beings may be exposed to heavy metals through consumption of contaminated foods such as rice(7). Heavy metals like $\mathrm{Fe}, \mathrm{Cu}, \mathrm{Zn}, \mathrm{Ni}$ and other trace elements are important for proper functioning of biological systems and their deficiency or excess could lead to a number of disorders ${ }^{(8)}$.

On this basis the presence of toxic heavy metals in rice, which may raise the metal daily intake, should be strongly avoided in order to prevent negative effects on human health. The following elements are considered macronutrients in rice and their content is usually in some percentage of $\mathrm{P}, \mathrm{S}, \mathrm{K}, \mathrm{Ca}$ and $\mathrm{Mg}$. Other elements, like $\mathrm{Mn}, \mathrm{Fe}, \mathrm{Cu}, \mathrm{Zn}$, $\mathrm{Se}$, and $\mathrm{Ni}$ are considered to be useful micronutrients to plants when used in amounts which facilitate the physical growth and development of plants ${ }^{(9)}$ and they are present in lower amount, while $\mathrm{As}, \mathrm{Cr}, \mathrm{Pb}$ and $\mathrm{Cd}$ are undesirable elements because of their toxic effects even in very low quantity. As a consequence, it is crucially necessary to reduce possible accumulation effects in rice grains from the environment for safe food production ${ }^{(10)}$. When these metals exceed maximum acceptable limits they become toxic to the plants. Just like in plants - $\mathrm{Fe}, \mathrm{Cu}, \mathrm{Mn}$ and $\mathrm{Zn}$ are useful in humans when used in trace amounts. When these metals exceed the acceptable limits in the body, they pose health problems ${ }^{(11)}$. Some of these health problems are cancer, hypertension, fever, kidney disorder and DNA damage in living cells ${ }^{(12)}$. Heavy metals are non-degradable and stay longer in the soil(13). Crops such as rice that are grown in submerged conditions are even more exposed to heavy metal sources both from the soil and water. Rice being the second most consumed crop in the world may in turn expose the majority of its consumers to the heavy metals ${ }^{(14)}$.

Heavy metals and trace elements are also a matter of concern due to their nonbiodegradable nature and long biological half-lives. Wastewater from industries or other sources carries sufficient amounts of toxic heavy metals such as $\mathrm{Cd}, \mathrm{Cu}, \mathrm{Zn}, \mathrm{Cr}, \mathrm{Ni}, \mathrm{Pb}$, and $\mathrm{Mn}$ in surface soil which create a problem for safe rational utilization of agricultural soil $^{(15)}$. Long-term use of industrial or municipal wastewater in irrigation is known to have a significant contribution to the content of trace and heavy elements such as $\mathrm{Cd}, \mathrm{Cu}$, $\mathrm{Zn}, \mathrm{Cr}, \mathrm{Ni}, \mathrm{Pb}$, and $\mathrm{Mn}$ in surface soil $(15,16)$. As a result, excessive accumulation of trace elements in agricultural soils through wastewater irrigation may not only result in soil contamination but also affect food quality and safety ${ }^{(17)}$. Karim et al. $2008^{(18)}$ conducted a study on the arsenic and heavy metal concentration in surface soils and vegetables of Feni district. 
The thermal decomposition reactions play an important role during different processes of the biomass utilization. Thermogravimetric analysis (TGA) is a quite precision method for the study of pyrolysis at control heating rates, under well-defined conditions in the kinetic system. It also provides information about the partial process and reaction kinetics. The thermal degradation patterns of lignocellulose biomass are strongly affected by their chemical composition such as cellulose, hemicellulose and lignin. A physical and thermo-chemical property of rice husk varies depending on the types of variety and geographical location of the cultivated crop. Physical properties such as particle size, moisture content and bulk density are important factors of any biomass. Transportability, flow ability and combustion characteristics are dependent on the physical properties. ${ }^{(19)}$

There are a few information regarding heavy metal concentrations and thermogravimetric analysis of soil-rice-husk system of the three different districts of Bangladesh. The aim of the present study was to determine the concentrations of heavy metals in soil, rice husk and rice grains produced in the three different districts (Gazipur, Savar and Chapainawabganj) of Bangladesh and to study the thermal properties of soil-rice-husk system. The metal contents of soils of the three districts were also correlated with the metals found in the crops grown the respected area which also supported by the TGA data.

\section{Materials and Methods}

Study areas: Soil and rice samples were collected from paddy fields of the districts in Bangladesh namely Savar, Chapainawabganj and two areas of Gazipur. Among these, two districts were selected from the industrial area near Dhaka city and other was apart from the industrial area in the north-western part of the Bangladesh, beside the Padma River.

Sample collection: Sampling of soil and paddy rice was conducted in January-February 2016 just before harvesting time. Soil samples were collected from 0 to $15 \mathrm{~cm}$ depth from corresponding rice samples cultivated paddy fields by random selection of the field at a specific distance. The collected soil samples were dried in air for a few days by spreading on a clean piece of paper. Visible roots and debris were removed from the soil samples and discarded. After air drying, a portion of the soils was ground by a wooden hammer. Ground samples were screened to pass through a $0.5 \mathrm{~mm}$ stainless steel sieve. Soils were preserved in plastic containers with proper labeling. Rice samples were collected from corresponding paddy fields for ensuring the original locations of samples. Paddy rice (rice grains with husks) was air dried to constant weight and husks were removed using mortar and pestle. The rice grain (paddy rice without husks) and husks were then separately ground to a fine powder. 
Digestion of samples: Well homogenized soil, rice grain and husk samples were weighed ( $0.5 \mathrm{~g}$ each) and taken into separate teflon vessel, then $10 \mathrm{ml}$ concentrated $\mathrm{HNO}_{3}$ was added in each digestion tube. The tubes were tightly closed with a cap provided with a hole to pass away of gases formed during the digestion. This procedure was performed according to US-EPA 3050B method ${ }^{(20)}$. The samples were placed in a CEM MARS XPRESS microwave and digested at $180^{\circ} \mathrm{C}$ for 20 minutes at 200 psi with a microwave power of $1600 \mathrm{~W}^{(21)}$. Both the digested samples of rice grain and rice husk were diluted with de-ionized water up to $25 \mathrm{ml}$ and digested soil samples were diluted up to $100 \mathrm{ml}$ in volumetric flasks. Powdered samples were preserved in a plastic container for thermogravimetric analysis at $600^{\circ} \mathrm{C}$.

Measurement of heavy metals: The concentrations of $\mathrm{Mn}, \mathrm{Fe}, \mathrm{Ni}, \mathrm{Cu}, \mathrm{Zn}, \mathrm{Cd}$ and $\mathrm{Pb}$ in the samples of rice grain, husk, and soil were determined by flame Atomic Absorption Spectrophotometer (AAS) (AAS 200, PerkinElmer). Standard solutions of corresponding metals were used to calibrate the instrument. Concentrations of all metals in soil, rice grain and husk samples are expressed on dry weight basis.

Thermogravimetric analyses: Thermogravimetric analyses (TGA) were carried out to measure the change in mass of samples as a function of time or temperature for characterization of multicomponent materials and thermal decomposition. TGA (TGA$50 \mathrm{H}$, Shimadzu) was performed from room temperature to $600^{\circ} \mathrm{C}$ in the presence of atmospheric nitrogen gas with a flow rate of $10 \mathrm{ml} / \mathrm{min}$ and temperature increase rate of $10^{\circ} \mathrm{C} / \mathrm{min}$, using aluminium crucibles and samples masses of $\sim 5 \mathrm{mg}$. The measurements were repeated at least three times for each sample.

\section{Results and Discussion}

Heavy metals concentrations in the soil, rice and husk samples were analyzed by AAS and are shown in Figs 1 - 5. The soil sample collected from Savar was found to be rich in $\mathrm{Mn}, \mathrm{Fe}, \mathrm{Ni}, \mathrm{Cu}$ and $\mathrm{Zn}$. The paddy grown in such soil might have absorbed these elements from the soil, and therefore, the husk and rice were also found to contain higher amount of these elements (Fig. 1). $\mathrm{Cd}$ and $\mathrm{Pb}$ were found to be below detection level (BDL) for soil and Cd was in a very low concentration in rice and husk.

The soil sample collected from Chapainawabganj was found to be rich in $\mathrm{Mn}, \mathrm{Ni}, \mathrm{Cu}$ and $\mathrm{Zn}$; whereas Fe was in very abundance in amount (Fig. 5). But the husk and rice obtained from corresponding paddy field contained comparatively lower amount of these elements than husk or soil (Fig. 2). $\mathrm{Cd}$ and $\mathrm{Pb}$ were also found at below detection level.

Likewise Savar and Chapainawabganj, soil samples of Gazipur region (Gazipur-1, Gazipur-2) were found to be rich in $\mathrm{Mn}, \mathrm{Ni}, \mathrm{Cu}$ and $\mathrm{Zn}$; whereas Fe was in abundance in

amount. But the rice obtained from corresponding paddy field also contained 
comparatively lower amount of these elements than husk or soil (Figs 3, 4). $\mathrm{Cd}$ and $\mathrm{Pb}$ were also found at below detection level.

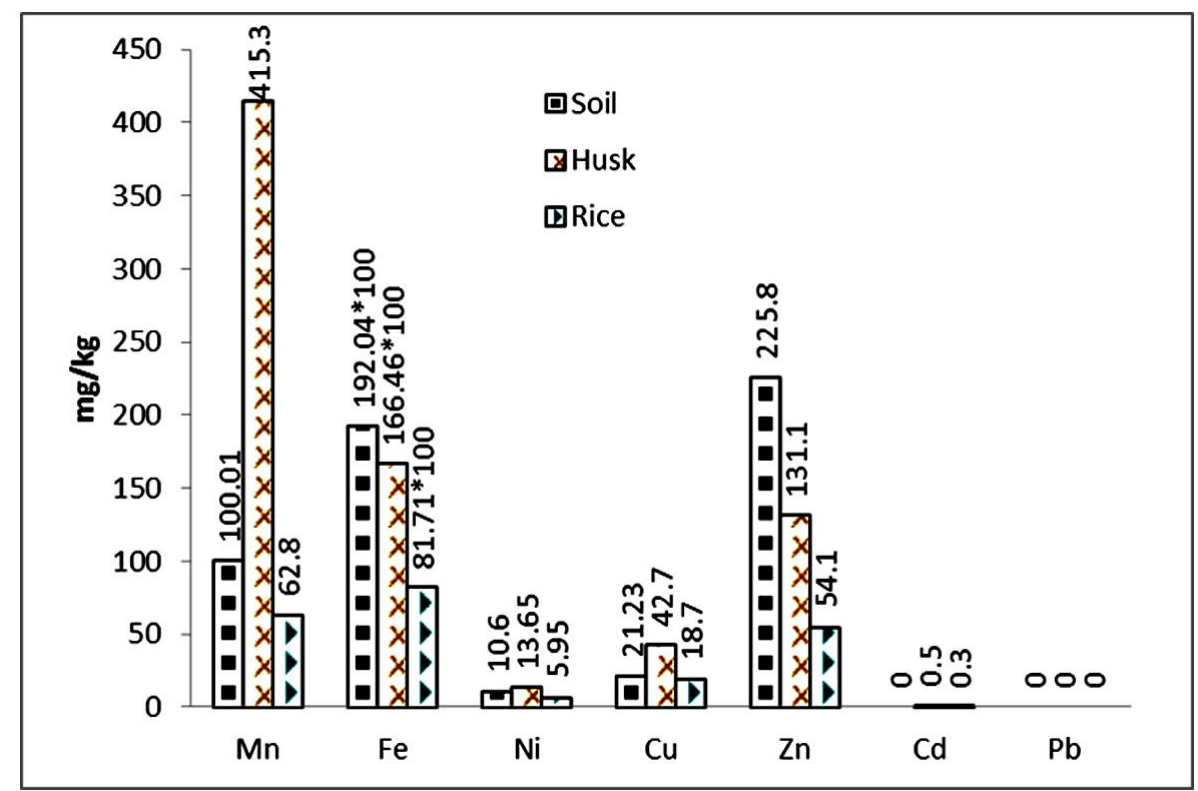

Fig. 1. Heavy metals content $(\mathrm{mg} / \mathrm{kg})$ of the samples collected from Savar.

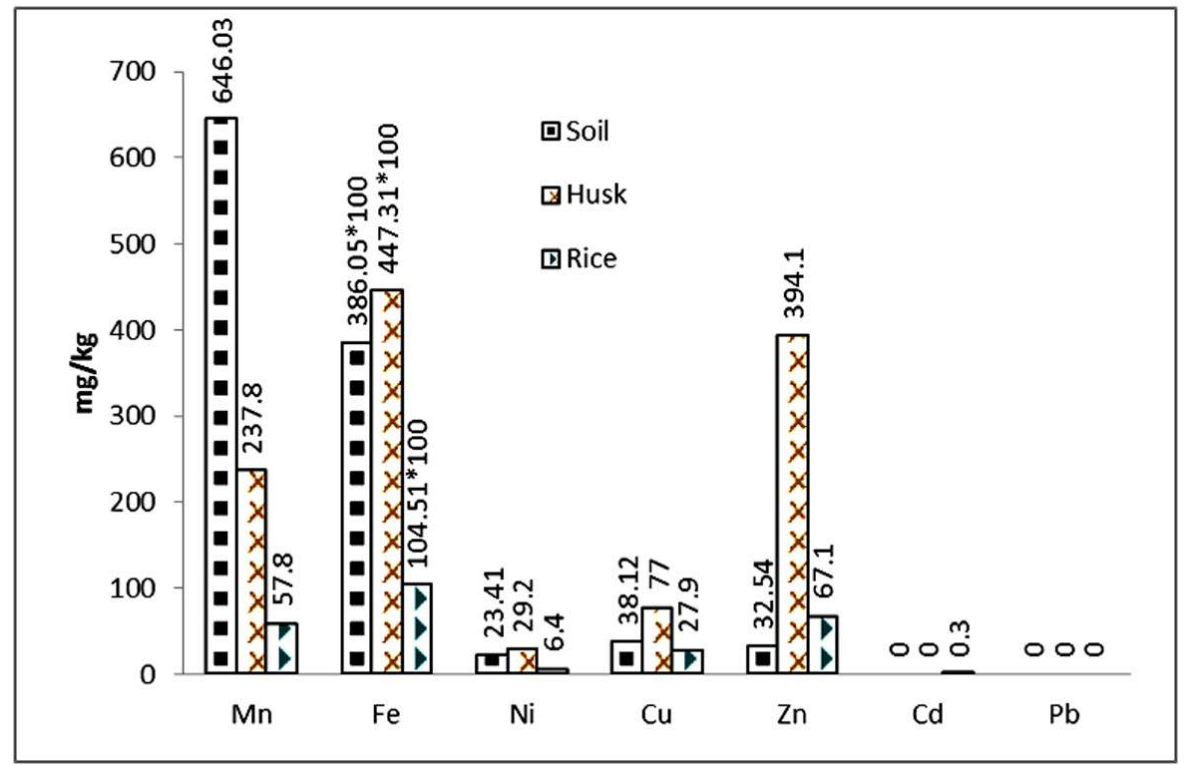

Fig. 2. Heavy metals content $(\mathrm{mg} / \mathrm{kg})$ of the samples collected from Chapainawabganj. 


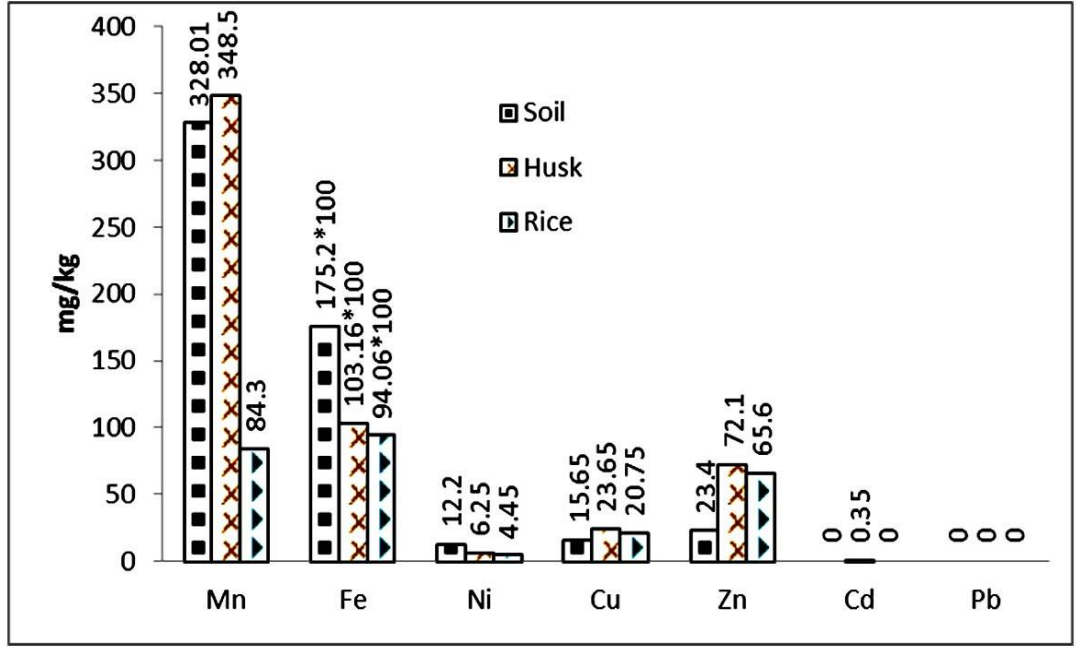

Fig. 3. Heavy metals content $(\mathrm{mg} / \mathrm{kg})$ of the samples collected from Gazipur-1.

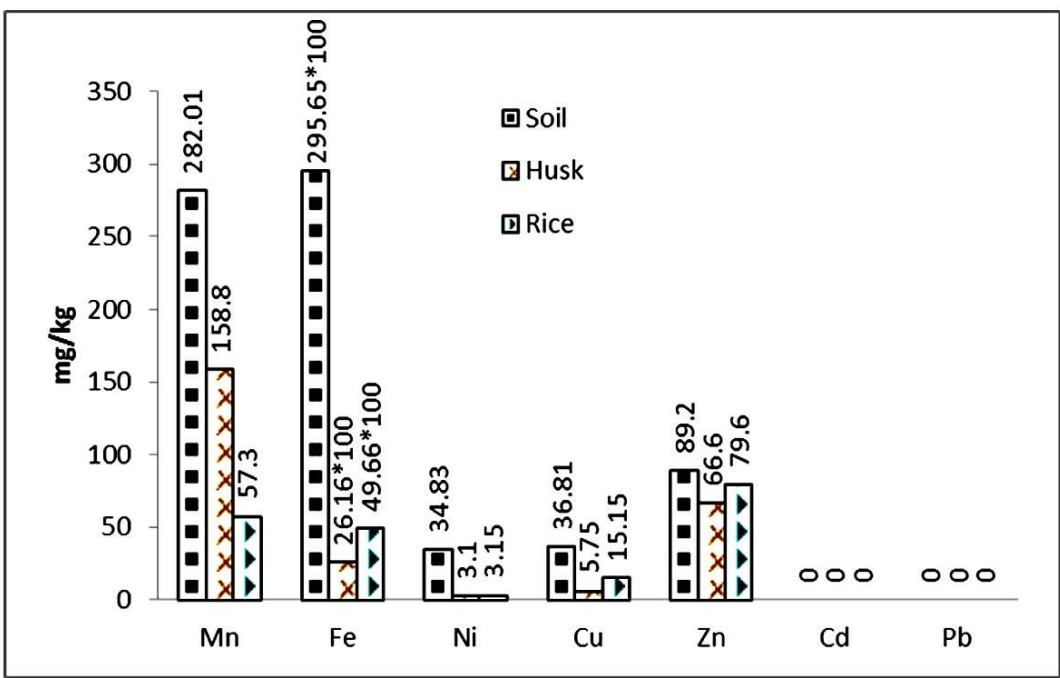

Fig. 4. Heavy metals content the samples collected from Gazipur-2.

Table 1. Heavy metals content acceptable limits $(\mathrm{mg} / \mathrm{kg})$ according to USEPA ${ }^{(22)}$ guidelines for sediments.

\begin{tabular}{lccccccc}
\hline Category & $\mathrm{Mn}$ & $\mathrm{Fe}$ & $\mathrm{Ni}$ & $\mathrm{Cu}$ & $\mathrm{Zn}$ & $\mathrm{Cd}$ & $\mathrm{Pb}$ \\
\hline Non polluted & $<300$ & $<17000$ & $<20$ & $<25$ & $<90$ & $*$ & $<40$ \\
Moderate polluted & $300-500$ & $17000-25000$ & $20-50$ & $25-50$ & $90-200$ & $*$ & $40-60$ \\
Heavily polluted & $>500$ & $>25000$ & $>50$ & $>50$ & $>200$ & $>6$ & $>60$ \\
\hline
\end{tabular}




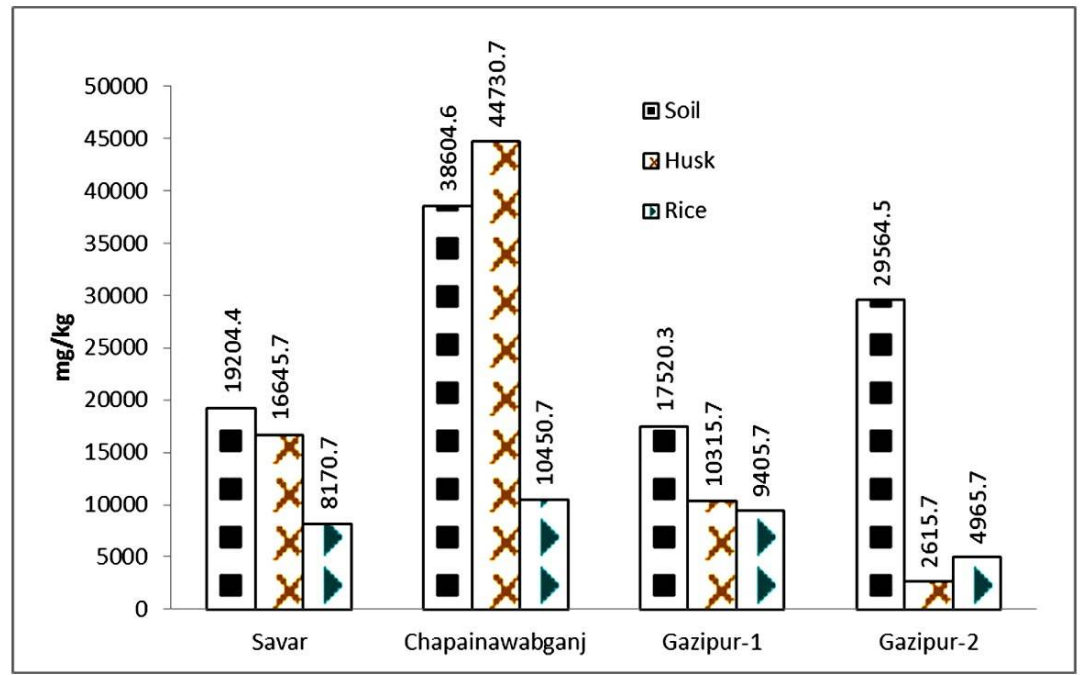

Fig. 5. Iron ( $\mathrm{Fe})$ content $(\mathrm{mg} / \mathrm{kg})$ of the samples.

According to the US Environmental Protection Agency (USEPA) guidelines (Table 1) soil of Chapainawabganj was found to be heavily polluted with Mn element whereas soil of Savar was non-polluted. The soils of Chapainawabganj and Gazipur-2 were heavily polluted with Fe than the other two sites (Savar and Gazipur-1), which were found to be moderately polluted. The element $\mathrm{Ni}$ and $\mathrm{Cu}$ of Savar and Gazipur-1 were found in nonpollution level, but Chapainawabganj and Gazipur-2 were moderately polluted. We also observed that in Savar, the $\mathrm{Zn}$ in soil was heavily polluted than that of the other three sites. Higher concentration of $\mathrm{Zn}$ in Savar area might be due to industrial activities, such as textiles, paints, battery, milling and chemical industries which might contaminate or introduce heavy metals into the soil(9).

From the Figs 1 - 5 it was seen that the descending order of the average contents of metals in rice as: $\mathrm{Fe}>\mathrm{Mn}>\mathrm{Zn}>\mathrm{Cu}>\mathrm{Ni}>\mathrm{Co}>\mathrm{Cd}>\mathrm{Pb}$. From results it was also observed that the concentration of $\mathrm{Pb}$ element in soil, husk and rice grain was below detection limit. Whereas the amount of $\mathrm{Cd}$ and $\mathrm{Pb}$ were in the soil below the detection limit but $\mathrm{Cd}$ element found in rice husk and rice grain. This was due to the rice grown in contaminated soil or through irrigation using groundwater or municipal wastewater ${ }^{(13)}$ and use of heavy metals containing agrochemicals such as pesticides, herbicides and fertilizers ${ }^{(12)}$. Heavy metals from the contaminated paddy soils may take place by the rice plant and accumulated in the grain ${ }^{(23)}$. According to the Codex Alimentarius Commission 2014 (24), heavy metal contamination in rice should not exceed the maximum limit of 0.4 $\mathrm{mg} / \mathrm{kg}$ for $\mathrm{Cd}$. The $\mathrm{Cd}$ concentration of rice grain from Savar and Chapainawabganj was found to be $0.3 \mathrm{mg} / \mathrm{kg}$, but the maximum tolerance level for $\mathrm{Cd}$ is $0.2 \mathrm{mg} / \mathrm{kg}$ for rice as stated by National Food Safety Standard 2012. This may be because of Cd from the 
industries and vehicle exhaust can pollute air which then can be absorbed directly by the rice grains ${ }^{(25)}$.

Fig. 6 shows thermograms (TG) for soil, husk and rice grain in (a) Chapainawabganj; (b) Gazipur-1; (c) Gazipur-2; and (d) Savar. A typical weight loss against temperature curve for the dehydration/pyrolysis of soil, rice and husk in nitrogen atmosphere under non isothermal conditions at heating rate of $10 \mathrm{C}$ /min from room temperature (RT) to $600^{\circ} \mathrm{C}$ was chosen as it produced highest degradation of the samples. The TG curve can be divided into three regions. The first region is drying zone, second is devolatilization zone and the third one is char formation zone ${ }^{(27)}$. In all rice, husk and soil samples, a mass loss within the temperature range from RT to $200^{\circ} \mathrm{C}$ was observed as a result of dehydration. The drying of the sample mainly occurred up to temperature $80-100^{\circ} \mathrm{C}$, where moisture released was 1.91, 9.45, 3.57 and $36.92 \%$ for soil of Savar, Chaapainawabganj, Gazipur 1 and Gazipur 2, respectively. Similarly moisture released as 7.87, $8.18,8.11$ and $8.24 \%$ for rice and $7.95,6.89,5.12$ and $5.66 \%$ for husk of the four respective places were found. From Fig. 6 it is seen that the dissociation patterns are almost same except for the thermogram of Gazipur 2 area. In this thermogram a rapid decrease of water in the soil was observed. It might be due to the higher initial moisture percentage of the soil sample (Table 2). The initial moisture could be higher in Gazipur 2 because of sampling just a few hours after rainfall.

Table 2. Moisture percentage of soil, rice grain and husk samples.

\begin{tabular}{lc}
\hline Area & Soil (\%) \\
\hline Savar & 3.12 \\
Chapainawabganj & 18.22 \\
Gazipur-1 & 20.34 \\
Gazipur-2 & 46.36 \\
\hline
\end{tabular}

The $63.65-67.48 \%$ mass loss occurs at $200-400^{\circ} \mathrm{C}$ for rice, for husk it was 53.64 $56.70 \%$, while for soil it was $1.26-3.20 \%$. Degradation within this temperature range could be attributed to the combustion of carbohydrates and other aliphatic compounds. The greater mass loss was observed in this temperature range for rice and husk. 3.2, $1.26,2.79$ and $2.26 \%$ of soil mass was loss at $200-400^{\circ} \mathrm{C}$ for Savar, Chapainawabganj, Gazipur 1 and Gazipur 2, respectively. The loss of mass could be an indicator of soil organic matter (SOM) present in that area. As a result it could be concluded that soil sample of Savar was rich in SOM, while soil of Chapainawabganj contained very low amount of SOM. Soil organic matter supplies necessary nutrient for the plant. So rich in soil organic matter may indicate the good fertility and productivity of the soil. The char yield occurred in the $400-600^{\circ} \mathrm{C}$ where could be the thermal degradation of carbonate and more stable aromatic structures occurred(26). The residual mass was found 1.55 - 
$2.57 \%$ for soil, $18.14-20.65 \%$ for rice and $17.34-21.18 \%$ for husk in the four places of the three districts which was found to be similar for residual mass of $13.82 \%$ observed for rice husk in Tanzania by Said et al. 2014(27).
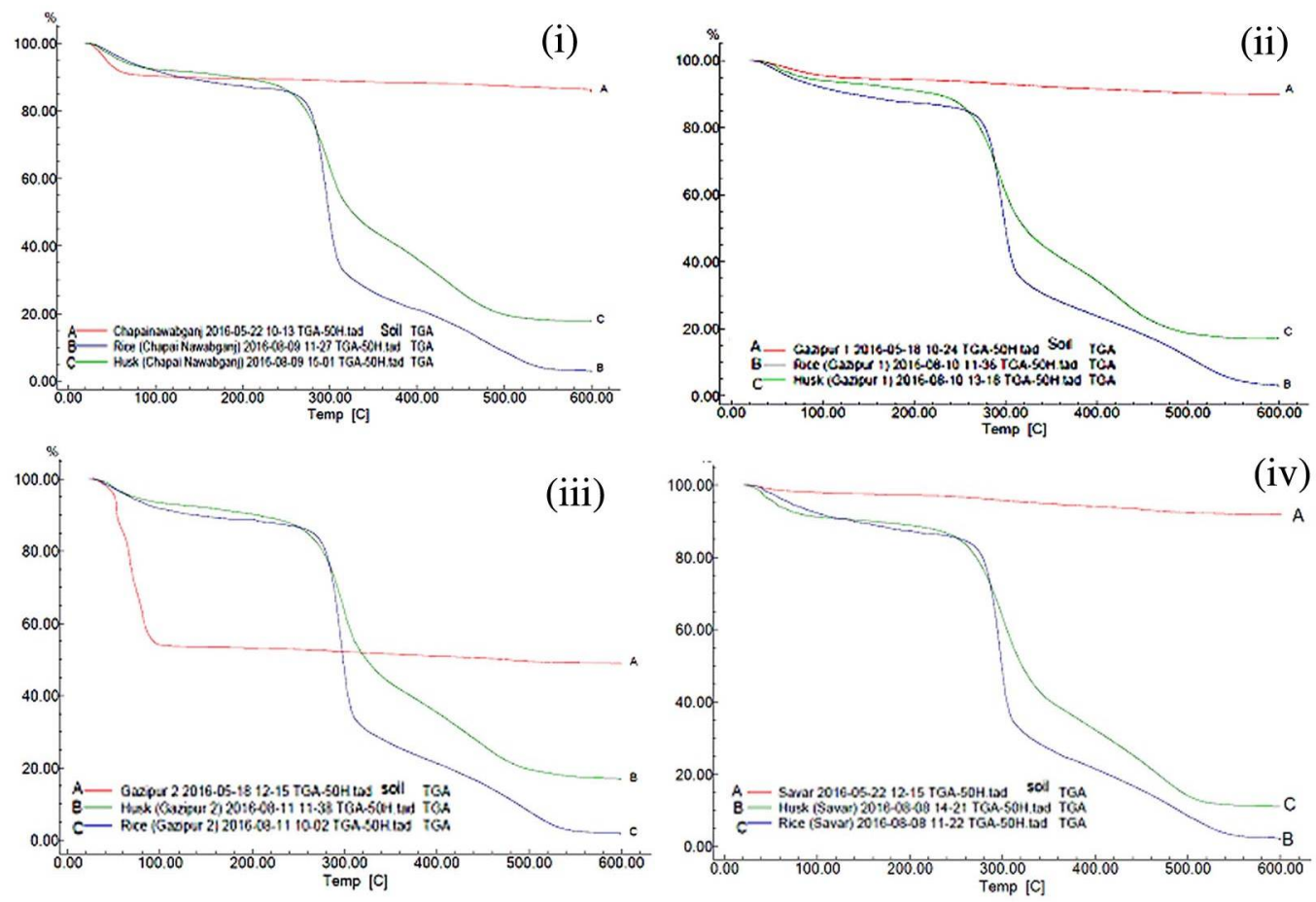

Fig. 6. TG curves for soil, husk and rice grain in (i) Chapainawaganj; (ii) Gazipur 1; (iii) Gazipur 2; and (iv) Savar.

The residual mass of the TG analysis could indicate the stable form or inorganic part of soil, rice and husk which would have supportive of heavy metal contents in the samples determined with AAS. The heavy metal content was relatively higher for rice and husk than found in the respected soil samples.

\section{Conclusion}

Soil is a great geochemical reservoir for contaminant as well as a natural buffer for transportation of chemical materials and elements in the atmosphere, hydrosphere, and biomass. In this paper, it was found that the metal composition of the soils of different regions were different in amount. It was also found that the accumulation of the metals in the crops corresponded to such metallic contents of the respected soils'. It indicated if the soil contained high amount of iron; the crops also contained high content of iron, and so on. 
It is obvious that the heavy metal contamination in the environment is of more concern worldwide. For this, it is the most important component of the human biosphere. The knowledge on the sources of heavy metals contamination in agricultural soils and rice is necessary in order to improve food safety by minimizing the possibility of food insecurity as well as human health problems. The most adverse effect of heavy metals is that they can be introduced into the food chain and threaten human health. Agricultural products growing on soils with high metal concentrations are represented by metal accumulations at levels harmful to human and animal health as well as to the bioenvironment. Therefore, the levels of heavy metals in rice should be monitored as rice is considered a source of energy for the large population in Bangladesh. The present National environmental policies should be reinforced to ensure that heavy metals contaminations in agricultural soils and in food crops are minimized. This will help in reducing health risk to the population at large.

\section{Reference}

1. Stone R 2008. Arsenic and paddy rice: A neglected cancer risk? Sci. 321(5886): 184-185.

2. Songul KAKSU, CELYK Guler and GUCER Seref 2004. Investigation of Trace Element Contents of Rice By ETAAS and ICP-MS, Adnan Menderes University, 4th AACD Congress, 29 Sept-3 Oct., Kuşadası-AYDIN, TURKEY Proceedings Book 284.

3. Web: https://en.wikipedia.org/wiki/Agriculture_in_Bangladesh (Access July, 2017).

4. Web: http://en.banglapedia.org/index.php?title=Rice (Access July, 2017).

5. Lin X, R Burns and G Lawrance 2005. Heavy metals of wastewater: the effect of electrolyte composition on the precipitation of cadmium (II) using lime and magnesia. Water Air Soil Pollut. 165: 131-52.

6. Rahman AKMR, SM Hossain and MM Akramuzzaman 2010. Distribution of heavy metals in rice plant cultivated in industrial effluent receiving soil. Environ. Asia 3(2): 15-19.

7. Machiwa JF 2010. Heavy metal levels in paddy soils and rice (Oryza sativa (L.)) from wetlands of Lake Victoria Basin, Tanzania. Tanz. J. Sci. 36: 59-72.

8. Rahmani HR and M Rezaei 2007. Effect of Industrial effluents of Zob-Ahan on soil, water and vegetable plants. J. Appl. Sci. Res. 7(17): 2519-22.

9. Simon F, KM Mtei and M Kimanya 2016. Heavy metals contamination in agricultural soil and rice in Tanzania: A review. Int. J. Environ. Protection Policy 4(1): 16-23.

10. Bilo F, M Lodolo, L Borgese, A Bosio, L Benassi, LE Depero and E Bontempi 2015. Evaluation of heavy metals contamination from environment to food matrix by TXRF: The case of rice and rice husk. J. Chem. 2015: 1-12.

11. Fernandez-Luqueno F, F Lopez-Valdez, P Gamero-Melo, S Luna-Suarez, EN Aguilera Gonzalez, AI Martinez, M Garcia-Guillermo, G Hernandez-Martínez, R Herrera-Mendoza, MA Alvarez-Garza and IR Perez-Velazquez 2013. Heavy metal pollution in drinking water - A global risk for human health: A review. Afr. J. Environ. Sci. Technol. 7(7): $567-584$.

12. Vanita C, C Piar, N Avinash, KJ Kaur and BJ Pakade 2014. Evaluation of heavy metals and its genotoxicity in Agricultural soil of Amritsar, Punjab, India. Int. J. Res. of Chem. Environ. 4: $20-28$. 
13. Zhao K, W Fu, Z Ye and C Zhang 2015. Contamination and spatial variation of heavy metals in the soil-rice system in Nanxun County, Southeastern China. Int. J. Environ. Res. Public Health 12: 1577-1594.

14. Emumejaye K 2014. Heavy and trace elements in some brands of rice consumed in delta state, Nigeria. IOSR. J. Appl. Phys. 6: 1-5.

15. Mapanda F, EN Mangwayana, J Nyamangara and KE Giller 2005. The effect of long-term irrigation using wastewater on heavy metal contents of soils under vegetables in Harare, Zimbabwe. Agric. Ecosys. Environ. 107: 151-165.

16. Rahman SH, D Khanam, TM Adyel, MS Islam, MA Ahsan and MA Akbor 2012. Assessment of heavy metal contamination of agricultural soil around Dhaka Export Processing Zone (DEPZ), Bangladesh: Implication of seasonal variation and indices. Appl. Sci. 2: 584-60.

17. Sharma RK, M Agrawal and F Marshall. 2008. Heavy metal ( $\mathrm{Cu}, \mathrm{Zn}, \mathrm{Cd}$ and $\mathrm{Pb})$ contamination of vegetables in urban India: A case study in Varanasi. Environ. Pollut. 154:254-263.

18. Karim RA, SM Hossain, MMH Miah, K Nehar and MSH Mubin 2008. Arsenic and heavy metal concentrations in surface soils and vegetables of Feni districts in Bangladesh. Environ. Monit. Assess. 145: 417-425.

19. Ahiduzzaman Md and AKM Sadrul Islam 2015. Thermogravimetric and kinetic analysis of different varieties of rice husk. Sixth BSME International Conference on Thermal Engineering (ICTE 2014). Procedia Engineering 105: 646-651.

20. Web: http://www.epa.gov/osw /hazard testmethods/sw846/pdfs/3050b.pdf (Access July, 2017).

21. Thompson M and JN Walsh 1989. Handbook of Inductively Coupled Plasma Spectrometry. Blackie and Son Ltd. Springer US. pp 316.

22. USEPA 1977. Guideline for the pollutional classification of great lakes harbor sediments, US Environmental Protection Agency, Region V, Chicago, April 1977.

23. Payus $C$ and AFA Talip 2014. Assessment of heavy metals accumulation in paddy rice (Oryza sativa). Afr. J. Agric. Res. 9: 3082-3090.

24. Codex Alimentarius Commission 2014. "Joint FAOMHO Food Standards Programme Codex Alimentarius Commission. Report of the eighth session of the Codex Committee on contaminants in foods," The Hague, The Netherlands, 31 March-4 April, 2014.

25. Lugwisha HE and OC Othman 2014. Levels of selected heavy metals in soil, tomatoes and selected vegetables from Lushoto district-Tanzania. Int. J. Environ. Monit. Anal. 2: 313-319.

26. Kristle M, M Mursec, V Sustar and J Kristle 2016. Application of thermogravimetric analysis for the evaluation of organic and inorganic carbon contents in agricultural soils. J. Therm. Anal. Calorim. 123: 2139-2147.

27. Said MM, RJ Geoffrey and FM Cuthbert 2014. Thernal characterstics and kinetics of rice husk for pyrolysis process. Int. J. Renew. Ener. Res. 4(2): 275-278. 